\title{
DOES IT MATTER HOW THE STUDENTS FEEL? PRACTICAL IMPLICATIONS OF SOCIAL RELATIONSHIPS IN SCHOOL
}

\author{
Maja Matric \\ University of Maribor, Faculty of Education, Slovenia \\ maja.matric@gmail.com
}

\section{Professional Paper doi:10.5937/jouproman6-19337}

\begin{abstract}
School cannot be merely defined as a content-learning environment, but also a context in which pupils learn social behaviour (Košir, 2013), which brings into question the role of social relationships in school. This is reflected in a growing number of research in the area of educational psychology examining the learning process beyond the cognitive scope, by establishing the role of peer relationships, social acceptance and other elements of social relationships in education (Pellegrini, \& Blatchford, 2000). Because of this, we cannot simply overlook the importance of social relationships children form within their peer groups. In the article, we include an overview of theoretical approaches which firmly place social relations in the learning process, and support these notions with relevant research literature. We also include practical guidelines and approaches which should prioritize social relationships in the making of positive school climate.
\end{abstract}

Keywords: social relationships, relatedness, peer support, EFL learning, peer relationships

\section{Introduction}

I believe we often draw a line between the quality of our time at work and the relationships we have with our co-workers. The experience can be pleasant, we can even extend our relationships beyond the workplace. On the other hand, our time at work can be plagued with poor relationships which affect our performance and well-being at the workplace. This led me to reconsider the importance of my students' well-being in the classroom in relation to their participation in school. In fact, I was interested in how their social status among their peers reflects on the learning process. As a teacher, I spend a lot of time with the students and have the opportunity to observe their behavioural patterns and social interactions. With this in mind, I write about the learning context and the students beyond the academic scope with the aim of exposing the social aspect of education.

\section{School as a social context}

Vygotsky (1978) claimed, that one of the main functions of learning is to create the zone of proximal development, i.e. an environment in which the learner activates numerous internal processes which lead to learning, provided there is an interaction with adults (teachers, parents) and peers. The author explains that participating in intellectual activities results from social and cultural influences and relationships with key persons from the educational contexts - the teachers and the peers. Therefore, defining school as a social context in which an individual learns academic content is not enough, as it is also the place where individuals learn social behaviours (Košir, 2013). 
Different ways in which the social context influences the actions and decisions of individuals are described by Bandura and Walters (1963) in the social learning theory from the standpoint of behaviouralcognitive theory. According to them, learning takes place within a specific context by imitating and reinforcing behaviours. Goodenow (1992) also supports the idea that learning is fundamentally a social process where the understanding of social context and mutual interpersonal and group processes typical in an educational setting is vital. In other words, we gain a lot of our knowledge individually, by observing our surroundings, experimenting, experiencing or reading. For the better part of this, we are accompanied by others - also in school, where personal relationships and interactions which occur in an educational context significantly influence the learning process. Goodenow (1992) also believes that understanding the student's psychological attachment to the social and interpersonal networks can improve motivational and learning aspirations of the student. Such views are creating a shift in the field of educational psychology from the research into cognitive aspects of education towards the understanding of social aspects of learning, i.e. by exploring the place of peer relationships, need for relatedness, group belonging, teacherstudent relationships, etc. (Pellegrini, \& Blatchford, 2000). Therefore, achieving social goals in school is equally as important as academic goals and considering both can help explain differences in students' academic performance (Wentzel, 1996). A number of authors have linked social goals to students' academic and social performance (Liem, 2016), long-lasting knowledge, effort and engagement (King, McInerney, \& Watkins, 2012), as well as the students' higher social acceptance and lower peer rejection (Mouratidis \& Sideridis, 2009) and prosocial behaviours (Ojanen, SmithSchrandt, \& Gesten, 2012). From this, we can conclude that the educational social context is a relevant aspect of the learning process, which I will further explore in terms of the need for relatedness as an indicator of quality of social relationships.

\section{The need for relatedness}

Self-determination theory focuses on different aspects of individual's functioning, such as personal development, self-regulation, universal psychological needs, energy, vitality, motivation and well-being, while keeping in mind the role of social surroundings (Deci \& Ryan, 2008). Of particular interest for this article is the effect of basic psychological needs for competence, autonomy and relatedness, defined by the self-determination theory as desirable conditions for an individual's performance (Deci \& Ryan, 2000). Competence determines an individual's belief in having the ability to influence important outcomes, autonomy relates to feelings of choice and self-regulation, while relatedness refers to having satisfying social relationships - which is the theme of this article. The need for relatedness is reflected in the social aspect of learning and the students should have the opportunity to develop positive social relationships with their teachers and peers, hence reducing the feelings of rejectedness and boosting students' motivation (Niemiec \& Ryan, 2009). 
In educational contexts, research has linked basic psychological needs to better academic outcomes (Bialis-White, 2013), increased self-regulation and well-being (Niemiec \& Ryan, 2009), higher motivation (Chirkov \& Ryan, 2001), and higher engagement and a more positive experience of the school setting (Klassen, Perry, \& Frenzel, 2012). In terms of social relationships in school, the need for relatedness can be defined as perceived peer personal and academic support and social acceptance, with both dimensions significantly affecting the students' active engagement in EFL (English as a foreign language) learning, as Matrić (2018) reveals that higher academic peer support results in higher motivation and more desirable behaviour in school, while higher personal peer support encourages the students to participate and engage in learning activities more. The author also reveals that socially accepted students who experience higher peer support feel less anxious in an EFL context, therefore experiencing less fear of communication, negative assessment and tests. These suggestions could help increase the role of social goals in education and this research does support the idea that social goals are an important part of active learning. The author concludes that higher perceived academic peer support, noticed by a student as the classmates wish that he/she does well at schoolwork, increases the students' motivation and improves their behaviour in school through higher emotional and behavioural engagement. This introduces more interest and higher participation in classes. Higher perceived personal support, when the student feels loved and cared for by his/her classmates, reduces anxiety which consequently reduces the fear of communicating, negative assessment and tests in classes. This supports the idea that peers can make lessons more enjoyable for those students who feel anxious, even though the key moderator of an appropriate peer context is still the teacher. Clearly, social aspects of education should not be neglected when learning a foreign language, as they can benefit the student significantly.

\section{Putting the theory into practice}

We have established that social relationships are an important part of the learning process and effort should be made to consciously implement approaches which raise awareness of the social aspects of learning. Each learning institution should pride itself on the social climate of the school and not only academic achievements of the students (Vogrinc, 2014; Ryan \& Brown, 2005; Ryan \& Weinstein, 2009). This can be achieved by fostering a positive attitude towards including social goals in the learning process and accepting social relationships as an indicator of quality of the learning organization. In theory, this is the case in Slovenia, as the social and emotional development of the children and acquiring social skills in an integral part of the curriculum (Krek \& Metljak, 2011). However, in teaching practice, Pompe (2016) finds that the curricula for the first three grades of elementary school do not include enough contents, related to social learning and children's psychosocial needs. We believe this shows a lack of experts from the areas of developmental and educational psychology actively engaged in the making of curricula. In addition, the schools should equip the teachers with the knowledge necessary for the development of the students' social skills. 
Unfortunately, this might not always be a priority for those offering various courses and workshops for teachers. The National Educational Institute of Slovenia, for example, offers a wide variety of content intended for the professional development of teachers in the areas of life-long learning, language competences of teachers, work with students with learning difficulties, implementing innovative learning approaches, the use of ICT, etc. (ZRSS, 2017; Katis, 2016/2017). However, we can notice a lack of contents related to social relations, peer support or social acceptance, which can hider or boost the students' motivation and interest in schoolwork and improve their emotional well-being. Once the teachers are educated in this area, they can included achieving social goals into their daily lesson plans, thus encouraging their students to accept their peers and speak of the quality of the relations they have with their classmates, as well as educating them that the way they are imbedded in the social network influences their schoolwork and achievements.

\section{References}

- Bandura, A., \& Walters, R. H. (1963). Social Learning and Personality Development. New York: Holt, Rinehart \& Winston.

- Bass-Dolivan, D. W. (2011). Students' engagement with second language learning: a sociocultural approach (Unpublishwd doctoral thesis). University of Wollongong, Faculty of Education, Wollogong.

- Chirkov, V., \& Ryan, R. (2001). Parent and teacher autonomy-support in Russian and U.S. adolescents: common effects on well-being and academic motivation. Journal of Cross-Cultural Psychology, 32(5), 618-635. https://doi.org/10.1177\%2F002202210103 2005006
- Crider, A. B., Goethals, G. R., Kavanaugh, R. D., \& Solomon, P. R. (1989). Psychology. Boston: Scott, Foresman and Company.

- Deci, E. L., \& Ryan, R. M. (2000). The »what « and »why« of goal pursuits: human needs in the self-determination of behaviour. Pshychological Inquiry, 11(4), 227-268.

- Deci, E. L., \& Ryan, R. M. (2008). Selfdetermination theory: A macrotheory of human motivation, development, and health. Canadian Psychology/Psychologie Canadienne, 49(3), 182-185.

- Goodenow, C. (1992). Strengthening the links between educational psychology and the study of social contexts. Educational Psychologist, 27(2), 177-197.

- Katis 2016/2017. Pridobljeno 2.8.2017 na https://lim3.mss.edus.si/katis/Katalogi/KA TALOG1617.pdf.

- King, R. B., McInerney, D. M., \& Watkins, D. A. (2012). Studying for the sake of others: The Role of social goals on academic engagement. Educational Psychology, 32(6), 749-776. http://dx.doi.org/10.1080/01443410.2012. $\underline{730479}$

- Klassen, R. M., Perry, N. E., \& Frenzel, A. C. (2012). Teachers' relatedness with students: An underemphasized component of teachers' basic psychological needs. Journal of Educational Psychology, 104(1), $150-$ 165. http://dx.doi.org/10.1037/a0026253

- Košir, K. (2013). Socialni Odnosi v šoli. Maribor: Subkulturni azil, zavod za umetniško produkcijo in založništvo.

- Krek, J. in Metljak, M. (Ur.). (2011). Bela knjiga o vzgoji in izobraževanju $v$ Republiki Sloveniji. Ljubljana: Zavod RS za šolstvo.

- Liem, G. D. (2016). Academic and social achievement goals: Their additive, interactive, and specialized effects on school functioning. British Journal of Educational Psychology, 86(1), 37-56. http://dx.doi.org/10.1111/bjep.12085

- Matrić, M. (2018). Vloga socialnih odnosov pri aktivnem vključevanju učencev $\mathrm{V}$ pouk angleškega jezika (Unpublished doctoral dissertation). 
Pedagoška fakulteta, Univerza $\mathrm{v}$ Mariboru.

- McCroskey, J. C. (1970). Measures of communication-bound anxiety. Speech Monographs, 37(4), 269-277.

- Mouratidis, A. A., \& Sideridis, G. D. (2009). On social achievement goals: Their relations with peer acceptance, classroom belongingness, and perceptions of loneliness. Journal of Experimental Education, 77(3), 285-307. https://doi.org/10.3200/JEXE.77.3.285-

308.

- Niemiec, C. P., \& Ryan, R. M. (2009). Autonomy, competence, and relatedness in the classroom: Applying selfdetermination theory to educational practice. Theory and Research in Education, $\quad 7(2), \quad$ 133-144. http://dx.doi.org/10.1177/1477878509104 $\underline{318}$

- Ojanen, T., Smith-Schrandt, H. L., \& Gesten, E. (2012). Associations among children's social goals, responses to peer conflict, and teacher-reported behavioral and academic adjustment at school. Journal of Experimental Education, 81(1), 68-83.

https://doi.org/10.1080/00220973.2011.63 $\underline{5167}$

- Ormrod, J. E. (2008). Human Learning (5th ed.). Upper Saddle River, NJ: Pearson Merrill Prentice Hall.

- Pellegrini, A. D. in Blatchford, P. (2000). The Child at School: Interactions with Peers and Teachers. Texts in Developmental Psychology. London: Arnold.

- Pompe, K. (2016). Socialno učenje V slovenski osnovni šoli (Diploma thesis). Dostopno na Dela FDV. Pridobljeno 2.8.2017 na http://dk.fdv.unili.si/dela/pompe-katarina.PDF

- Ryan, R. M., \& Brown, K. W. (2005). Legislating competence: The motivational impact of high-stakes testing as an educational reform. In C. Dweck and A. Elliot (Eds.), Handbook of Competence (354-374). New York: Guilford Press.

- Ryan, R. M., \& Weinstein, N. (2009). Undermining quality teaching and learning. A self-determination theory perspective on high-stakes testing. Theory and Research in Education, 7(2), 224233.

- Sarason, I. G. (1978). The Test Anxiety Scale: Concept and research. In C. D. Spielberger \& I. G. Sarason (Eds.), Stress and Anxiety, Vol. 5. (193-216). Washington, D. C.: Hemisphere Publishing Corporation.

- Svet Evrope (2011). Skupni evropski jezikovni okvir: učenje, poučevanje, ocenjevanje. Ljubljana: Ministrstvo RS za šolstvo in šport. (Prevod dela Common European Framework of Reference for Languages: Learning, teaching, assessment, 2001. Cambridge: CUP.)

- Vogrinc, J. (2014). Dopis Državne komisije za vodenje NPZ. Pogledi, 6 (23). Pridobljeno $\quad 2.8 .2017 \quad$ na http://pogledi.delo.si/druzba/dopisdrzavne-komisije-za-vodenje-npz.

- Vygotsky, L. S. (1978). Mind in Society: The Development of Higher Psychological Processes. Cambridge, Mass.: Harvard University Press.

- Watson, D., \& Friend, R. (1969). Measurement of Social-Evaluative Anxiety: Erratum. Journal of Consulting and Clinical Psychology, 33(4), 448-457.

- Wentzel, K. R. (1996). Social and academic motivation in middle school: Concurrent and longterm relations to academic effort. Journal of Early Adolescence, 16(4), 390-406. http://dx.doi.org/10.1177/0272431696016 004002

- Wilson, V. A. (1999). Reducing Statistics Anxiety: A Ranking of Sixteen Specific Strategies. Predstavljeno na Mid-South Educational Research Association. Point Clear, Alabama.

- Zavod RS za šolstvo in šport. Pridobljeno 2.8.2017 na http://www.zrss.si/inovativnijavni-zavod/zrss/. 